\title{
Investigation of cytotoxicity induced by Nigella sativa and Azadirachta indica using MDA-MB-231, HCT 116 and SHSY5Y cell lines
}

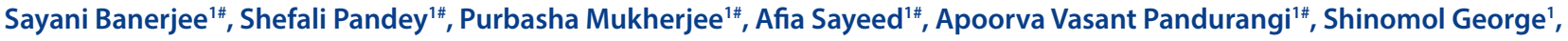 \\ Sahabudeen Sheik Mohideen ${ }^{2 *}$
}

\section{Sayani Banerjee ${ }^{1 \#}$, Shefali Pandey" ${ }^{1 \#}$, Purbasha Mukher- jee $^{1 \#}$, Afia Sayeed $^{1 \#,}$, Apoorva Vasant Pandurangi ${ }^{\prime \#}$, Shinomol George', \\ Sahabudeen Sheik Mohideen ${ }^{2 *}$ \\ 'Department of Biotechnology, Day- ananda Sagar College of Engineering, \\ Kumaraswamy Layout, Bangalore -560 078, Karnataka, India. \\ 2Department of Biotechnology, School of Bioengineering, SRM University, Kat- tankulathur - 603 203, Kancheepuram Dist., Tamil Nadu, India. \\ \#All authors contributed equally. \\ Correspondence}

Sahabudeen Sheik Mohideen,

Department of Biotechnology, School of Bioengineering, SRM University, Kattankulathur - 603 203, Kancheepuram Dist., Tamil Nadu, India.

Phone: +91 9790421460

E-mail: sahabudeen@gmail.com

History

- Submission Date: 21-09-2016;

- Review completed: 10-10-2016;

- Accepted Date: 16-10-2016.

DOI : 10.5530/pj.2017.2.31

Article Available online

http://www.phcogj.com/v9/i2

\section{Copyright}

(C) 2017 Phcog.Net. This is an openaccess article distributed under the terms of the Creative Commons Attribution 4.0 International license.

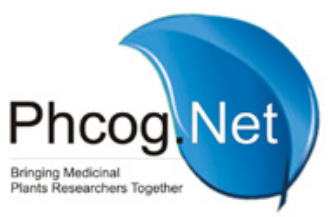

\begin{abstract}
Background: Indian herbal plants are widely used as medicine in the ancient ayurvedic and culinary purposes. Nigella sativa that also called as in black cumin is a flowering plant in the family ranunculiceae that is native to Southeast Asia. More recently Nigella sativa is also been used as anti cancer drug and protective agent against gamma radiation induced adverse effects in cell lines. Azadirachta indica commonly called as neem, is a tree belonging to mahogany family meliaceae. Azadirachta indica is also a traditional medicinal plant that used from a very long time in Indian ayurvedic and it is also been reported to have many beneficial effects including but not limited to anti-cancer and anti-diabetic effects. Objective: Find the $\mathrm{IC}_{50}$ values of Nigella sativa and Azadirachta indica ethanolic extracts in MDA-MB-231, HCT 116 and SHSY5Y cell lines. Methods: In this study we selected two cancerous cell lines (MDA-MB-231, HCT 116) and one neuronal cell line (SHSY5Y) and studied the effect of the two plant extracts namely Nigella sativa and Azadirachta indica on the cell metabolic activity. Results: This study revealed that cancerous cell lines are more prone to the plant extracts than the neuronal cell lines. These results suggest positive clues on how such medicinal plant extracts act against cancerous cells alone while affecting the normal cells to a limited extent. However, further studies are required to find if this effect is due to cytotoxicity, cytostaticity, or anti-adhesive property.
\end{abstract}

Key words: Herbal plants, Ayurvedic medicine, Cancer cells, Neuronal cells.

\section{INTRODUCTION}

In the recent times an exponential growth in the field of herbal medicine has been observed and these drugs are gaining popularity both in developing and developed countries because of their natural origin and reduced side effects. ${ }^{1,2}$ Many traditional medicines in use are derived from medicinal plants, minerals and organic matter and a number of medicinal plants, termed rasayana are used in the Traditional Indian health care systems have been in use for over 1000 years. Among the 21,000 plants listed by The World Health Organization (WHO) which are used for medicinal purposes around the world, 2500 species are in India, out of which 150 species are used commercially on a fairly large scale. India is the largest producer of medicinal herbs and is very aptly known as the botanical garden of the world. ${ }^{3}$

Azadirachta indica commonly called as neem is being traditionally used from a very long time due to its various beneficial effects including anti-cancer and anti-diabetic effects. ${ }^{4}$ More recently Nigella sativa commonly called as black cumin, is also being used in cancer treatment and is also a protective agent against gamma radiation-induced adverse effects in cell lines. ${ }^{5,6,7}$ In order to understand the effects of the plants on the cell metabolic activity, the plant extracts were prepared and we selected two cancerous cell lines (MDA-MB-231- breast adenocarcinoma, HCT116 - colon carcinoma) and one non-cancerous neuronal cell line (SHSY5Y). This approach is thus made in order to develop successful therapeutic modalities for anticancer activity. The development of such drugs will require a comprehensive understanding of the characteristics of cancer cells as well as applying modern technologies for drug delivery. This paper emphasis on medicinal plant based therapeutics to ascertain whether herbal extracts differentially cause cell death in cancer and normal cells.

\section{METHODOLOGY}

\section{Materials Used}

(3-[4,5-dimethylthiazol-2-yl]-2, 5-diphenyl tetrazolium bromide) or MTT, DMSO.95\% ethanol. All chemicals and reagents used were of analytical quality.

\section{Plant extracts preparation}

The Nigella sativa seeds and Azadirachta indicaleaves were washed with water, shade dried and extracted by boiling $500 \mathrm{~g}$ of the seed powder (twice) in $3000 \mathrm{~mL}$ of $95 \%$ Ethanol for $30 \mathrm{~min}$ at $70^{\circ} \mathrm{C}$ in a soxhlet extraction unit. The extract obtained was flash evaporated and concentrated on a water bath at 
atmospheric pressure to a semisolid condition, which was further dried in an oven at $30^{\circ} \mathrm{C}$ on a shallow dish to remove the solvent completely.

\section{Phytochemical screening}

Preliminary phytochemical analysis of the extract was performed by simple chemical tests.

\section{MTT Assay}

The cells were seeded at 50,000 cells / well (HCT-116, SHSY5Y, MDAMB231) in a 96 well plate and incubated for $24 \mathrm{hrs}$ at $37^{\circ} \mathrm{C}, 5 \%$ $\mathrm{CO}_{2}$ incubator. The samples to be tested were added from $0-320 \mu \mathrm{g} / \mathrm{ml}$ ( 2 fold variation) concentration of DMEM without FBS was incubated for $24 \mathrm{hrs}$.After incubation the test samples were added with $100 \mu \mathrm{l} /$ well (50 mg /well) of the MTT ( $5 \mathrm{mg} / 10 \mathrm{ml}$ of MTT in 1 X PBS) to the respective wells and incubated for 3to 4 hours (Figure 1).After incubation, the MTT reagent was discarded by pipetting without disturbing cells and $100 \mu \mathrm{l}$ of DMSO was added to rapidly solubilize the formazan. The Absorbance was measured at $590 \mathrm{~nm}{ }^{8,9}$

\section{RESULTS AND DISCUSSION}

Nigella sativa and Azadirachta indica extract samples were tested by MTT assay ${ }^{11,12}$ and the following results were obtained for three different cell lines HCT116, MDAMB231 and SHSY5Y. All the cell lines were tested with various concentrations of plant extracts 10,20, 40, 80, 160 and $320 \mu \mathrm{g} / \mathrm{ml}$. And a graph was drawn with extract concentration as $\mathrm{x}$-axis and corresponding observance at $590 \mathrm{~nm}$ as $\mathrm{y}$-axis. The $\mathrm{IC}_{50}$ value was calculated from drawing a tread line connecting all the points plotted and an equation for the line was generated. Using the equation $\mathrm{IC}_{50}$ value was obtained as 119.5, 125.8 and $224.7 \mu \mathrm{g} / \mathrm{ml}$ for HCT116, MDAMB231 and SHSY5Y cell lines in the case of Nigella sativa. And in the case of Azadirachta indica 50.52, 131.1 and $162.8 \mu \mathrm{g} / \mathrm{ml}$ for HCT116, MDAMB231 and SHSY5Y cell lines. The calculated $\mathrm{IC}_{50}$ values are mentioned in Table 1 and the detailed observance and corresponding $\%$ inhibition of growth for each cell line and samples are mentioned below in Table 2.

The half maximal inhibitory concentration $\left(\mathrm{IC}_{50}\right)$ is a measure of the effectiveness of a substance in inhibiting a specific biological or biochemical function. ${ }^{13}$ This quantitative measure indicates how much of a

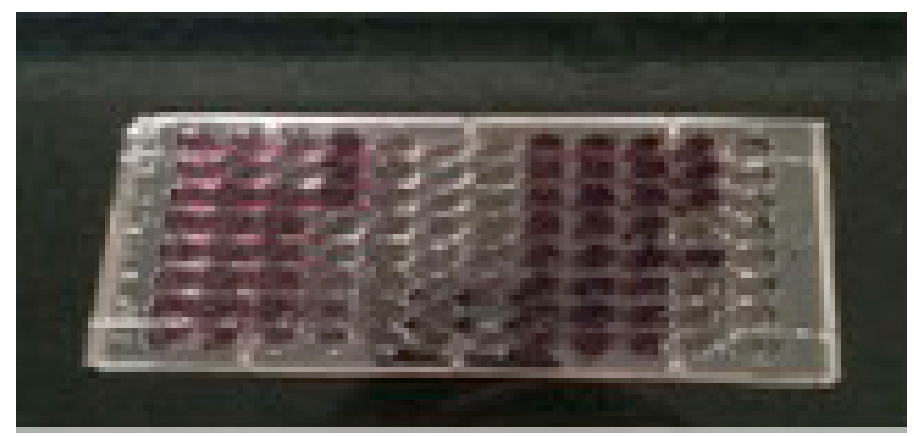

Figure 1: MTT assay microplate.

Table 1: IC ${ }_{50}$ values of Nigella sativa and Azadirachta indica in HCT116, MDAMB231 and SHSY5Y

\begin{tabular}{ccc}
\hline Cell lines & $\mathrm{IC}_{50} \begin{array}{c}\mathrm{\mu g} / \mathrm{ml}(\text { Nigella } \\
\text { sativa })\end{array}$ & $\begin{array}{c}\mathrm{IC50} \mu \mathrm{g} / \mathrm{ml} \text { (Azadirachta } \\
\text { indica) }\end{array}$ \\
\hline MDAMB231 & 125.8 & 131.1 \\
HCT116 & 119.5 & 50.52 \\
SHSY5Y & 224.7 & 162.8 \\
\hline
\end{tabular}

Table 2: MTT assay values, observance at 590 nm, \% inhibition and IC values of extracts

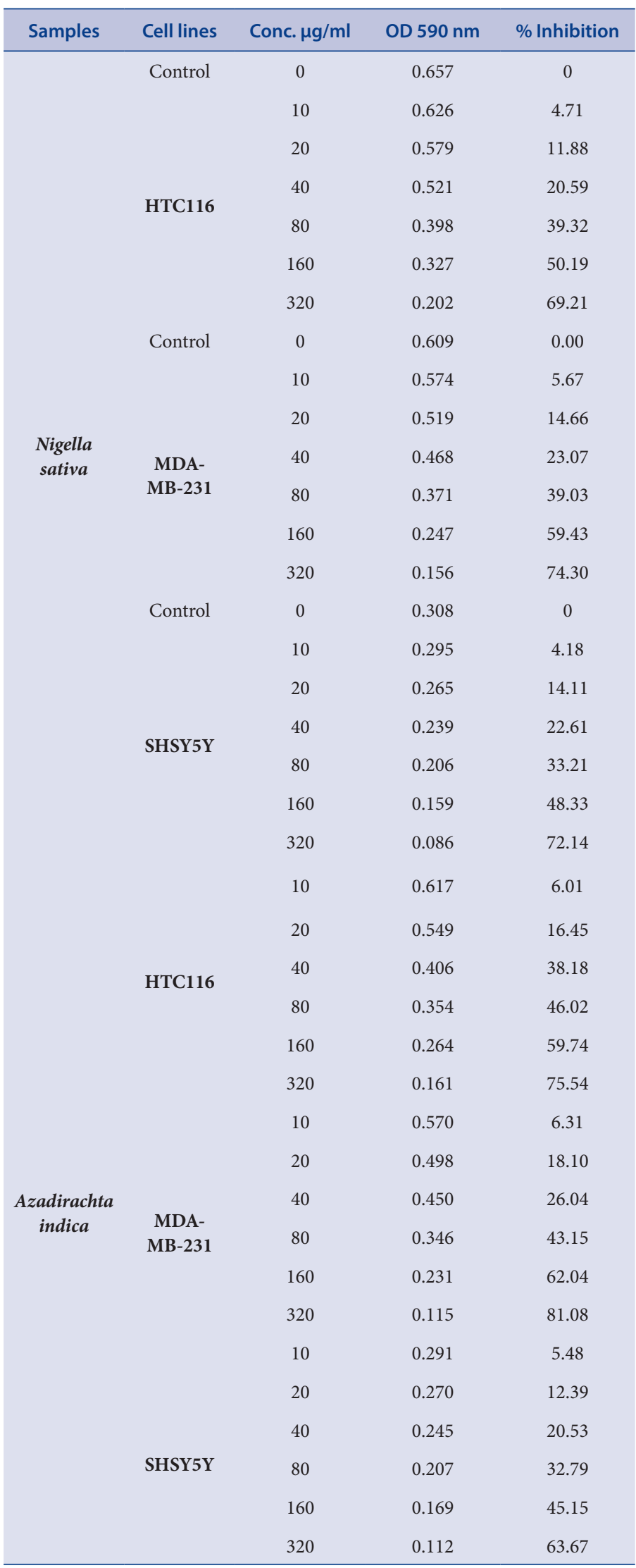


particular drug or other substance (inhibitor) is needed to inhibit a given biological process (or component of a process, i.e. an enzyme, cell or microorganism by half. The results suggest that the plant extracts Nigella sativa andAzadirachta indica have effects on HCT-116, SHSY5Y and MDAMB231 cell metabolic activity compared to control and can be considered for further studies. Nigella sativa and Azadirachta indica extract has the advantages of easy availability, low cost and safety to humans, which collectively make plant derived compounds valuable candidates for anticancer therapy. Preclinical studies have primarily established neem as a potential preventive and therapeutic agent against various types of cancer. Many investigators now believe that traditional medicine is a promising source of new therapeutics against cancer. Extensive research with Nigella sativa and Azadirachta indica may contribute to the discovery of new anticancer strategies.

The \%inhibition is calculated using the formula:

\% Inhibition $=100-(O D$ of sample $/ O D$ of Control $) \times 100$.

\section{CONCLUSION}

This study revealed that cancerous cell lines are more prone to the effects of the plant extracts than the neuronal cell lines. These results suggest positive clues on how such medicinal plant extracts act against cancerous cells alone while affecting the normal cells to a limited extent. ${ }^{14}$ Therefore, this preliminary study will lead to study the mechanism behind this effect.

\section{ACKNOWLEDGEMENTS}

The authors are thankful to the valuable suggestions of Dr. S. Sujatha, Assistant Professor, Department of Biotechnology, SRM University.

\section{CONFLICT OF INTEREST}

The authors declare no conflict of interest.

\section{REFERENCES}

1. Manisha M, Priyanjali D, JayantL, Saroj G, Thomas PAD. Indian herbs and herbal drugs used for the treatment of diabetes. J Clin Bio chem Nutr, 2007;27;40(3):163-73. http://dx.doi.org/10.3164/jcbn.40.163 PMid:18398493 PMCid:PMC2275761.

2. Prasanna KK, Ravi TM. Effect of moringa oleifera on blood glucose, Idl levels in types ii diabetic obese people. Innovative Journal of Medical and Health Science, 2013;1(3):23-25.

3. Ruchi T, Amit KV, Sandip C, Kuldeep D, hoor V S. Neem (Azadirachta indica) and its Potential for Safeguarding Health of Animals and Humans:
A Review. Journal of Biological Sciences, 2014;14(2):110. http://dx.doi. org/10.3923/jbs.2014.110.123

4. Asaduzzama K, Han-chun C, Mousumi T, Dian-zheng Z. Anticancer Activities of Nigella Sativa (Black Cumin). Afr J Tradit Complement Altern Med, 2011;8(5):226-32.

5. Crouch SPM, Kowzlowski R, Slater KJ, Fletcher J. The use of ATP bioluminescence as a measure of cell proliferation and cytotoxcity. J. Immunol. Meth. 1993;160(1):81-8. http://dx.doi.org/10.1016/0022-1759(93)90011-U.

6. Gonzalez RJ, Tarloff JB. Evaluation of hepatic sub cellular Fractions for alamar blue and MTT Reductase activity. Toxicology in vitro. 2001;15(3):257-9. http:// dx.doi.org/10.1016/S0887-2333(01)00014-5.

7. Hattori N, Sakakibra T, Kajiyama N, Igarashi T, Madea M, Murakami S. Enhanced microbial biomass assay using mutant luciferase resistant to benzalkonium chloride. Anal Bio chem. 2003;319(2):287-95. http://dx.doi.org/10.1016/S00032697(03)00322-1.

8. Kangas L, Gronroos N, Niemnen AL. Bioluminescence of cellular ATP: A new method for evaluating cytotoxic agents in vitro. Med Biol. 1984;62(6): 338-43. PMid:6543460.

9. Lundin, A, Hasenson M, Persson J, Ake P. Estimation of biomass in growing cell lines by adenosine triphosphate assay, Methods enzymol. 1986; 133:27-42. http://dx.doi.org/10.1016/0076-6879(86)33053-2.

10. Cell Viability and Proliferation. Mark Frei, BioFiles 5(6):17-21.

11. Denizot FF, Lang RR. Rapid colorimetric assay for cell growth and survival. Modifications to the tetrazolium dye procedure giving improved sensitivity and reliability. Journal of Immunological Methods 1986;89(20):27-7.

12. Mosmann TT. Rapid colorimetric assay for cellular growth and survival application to proliferation and cytotoxicity assays. Journal of Immunological Methods, 1983;65(1-2):55-63. http://dx.doi.org/10.1016/0022-1759(83)90303-4.

13. Slater TF. Free-radical mechanisms in tissue injury. Bio chem. J 1984;222(1):115. http://dx.doi.org/10.1042/bj2220001; PMid:6383353 PMCid:PMC1144137.

14. Valentao P, Fernandes E, Carvalho F, Andrade PB, Seabra RM, Bastos ML. Anti-oxidant activity of Hypericum androsaemum Infusion: Scavenging Acivity against superoxide radical, hydroxyl radical and hypochlorous acid. Biol Pharm Bull, 2002;258(10):1320-3

15. Gow-Chin Y, Pin DD. Scavenging effect of methanolic extracts of peanut hulls on free radical and active oxygen species. J Agric Food Chem, 1994;42(3):629-32 http://dx.doi.org/10.1021/jf00039a005.

16. Aragon SM, Basabe B, Benedi JM, Villar AM. Antioxidant activity of Vaccinium myrtillus L. Phytother. Res. 1998;12(S1):S104-S6. http://dx.doi.org/10.1002/ (SICI)1099-1573(1998)12:1+<S104::AID-PTR265>3.0.CO;2-O.

17. Hemant RJ, Bhutani KK. Antioxidant properties of Indian Medicinal plants. Phytother. Res. 2002;16(8):771-3. http://dx.doi.org/10.1002/ptr.1063; PMid:12458486.

18. Buritis M, Bucar F. Antioxidant activity of Nigella sativa essential oil. Phytother. Res. 2000;14(5):323-8. http://dx.doi.org/10.1002/1099-1573(200008) 14:5<323::AID-PTR621>3.0.CO;2-Q.

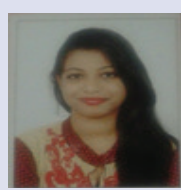

\section{ABOUT AUTHORS}

Sayani Banerjee: Persuing final year BE in Biotechnology from Dayananda Sagar College of Engineering, Bangalore. Involved in toxicology research on animal cell lines.

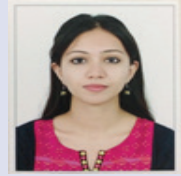

Shefali Pandey: Persuing final year BE in Biotechnology from Dayananda Sagar College of Engineering, Bangalore. Involved in toxicology research on animal cell lines.

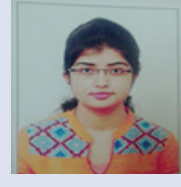

Purbasha Mukherjee: Persuing final year BE in Biotechnology from Dayananda Sagar College of Engineering, Bangalore. Involved in toxicology research in animal cell lines. 


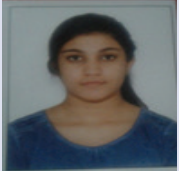

Afia Sayeed: Persuing finla year BE in Biotechnology from Dayananda Sagar College of Engineering, Bangalore. Involved in toxicology research in animal cell lines.

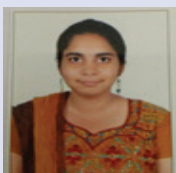

Apoorva Vasant Pandurangi- Persuing final year BE in Biotechnology from Dayananda Sagar College of Engineering, Bangalore. Involved in toxicology research on animal cell lines.

Dr. Shinomol George K- Is an Assistant Professor in the Department of Biotechnology, Dayananda Sagar College of Engineering, Banaglore. Her research interests are Neurobiology and Environmental Neurotoxicity.

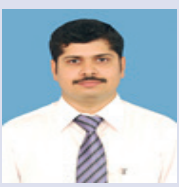

Dr. S. Sahabudeen- Is an Associate Professor in the Department of Biotechnology, SRM University, Chennai. His research interests are Neurotoxicity, Neurodegenerative diseases, Alzheimers disease, Drug discovery and Medicinal plant compounds.

Cite this Article: Banerjee S, Pandey S, Mukherjee P, Sayeed A, Pandurangi A, George SK, Mohideen SS. Investigation of cytotoxicity induced by Nigella sativa and Azadirachta indica using MDA-MB-231, HCT 116 and SHSY5Y cell lines. Pharmacogn J. 2017;9(2):192-5. 